Антон БУЗОВ

аспірант, Донецький національний університет імені Василя Стуса

\title{
ФАБУЛЬНА ОРГАНІЗАЦІЯ РОМАНУ ВІТАЛІЯ БЕНДЕРА «МАРШ МОЛОДОСТИ»
}

У статті здійснено аналіз роману українського письменника-емігранта Віталія Бендера «Марш молодости» на фабульному рівні. У творі послідовно виділені фази обособлення, встановлення партнерства, смертельного випробування, перевтілення. Використання класичних сюжетних схем під час дослідження літературного доробку української діаспори дозволяє повніше розкрити не лише загальнолюдський пафос та гуманістичну спрямованість цих текстів, але й їх ідейно-естетичну своєрідність.

Ключові слова: роман, еміграція, фабула, сюжет, система сюжетного розвитку, поетика.

Віталій Бендер $є$ одним із тих представників української письменницької еміграції, чия творчість, лишаючись частково поцінованою за кордоном, лише в останні роки повертається до вітчизняного читача. Мова йде про письменника, хоч і не першорядного (чому сприяла потужна «тінь» старшого товариша й учителя Івана Багряного), але досить помітного в дискурсі еміграційного літературного українства.

Епічні та публіцистичні твори Віталія Бендера до цього часу не знайшли значного поцінування у вітчизняному літературознавстві. У словникудовіднику «Українська діаспора: літературні постаті, твори, біобібліографічні відомості» за редакцією Віри Просалової [11] постать письменника розглянуто передовсім у біографічному вимірі. Короткі спогади про Бендера належать Р. Василенку [4], М. Дальному [6], І. Качуровському [7]. Інформативною, знову ж таки, щодо біографічних відомостей є передмова О. Коновала [8] до найповнішого на сьогодні видання творів письменника, проте дослідник у ній зовсім оминає питання фахового аналізу текстів Віталія Бендера, зосереджуючись лише на їх перерахуванні.

Згадані розвідки $є$ виявом бодай побіжного інтересу до постаті письменника. Проте в деяких спеціалізованих виданнях, у яких об'єктом дослідження постає літературний процес української еміграції, навіть не 
згадується ім’я Віталія Бендера. Так, монографія В. Мацька «Українська еміграційна проза XX століття» [10] не містить жодної згадки про письменника та його творчість як один 3 феноменів еміграційної епіки, незважаючи на те, що в назві праці наявна настанова на вичерпність у ній фахового розгляду діаспорної прози.

Літературно-критична рецепція творчого доробку митця представлена кількома розвідками сучасних українських літературознавців. У статті Віри Просалової розглянуто реалізацію проблеми «автор-герой» у романі «Фронтові дороги» [12]. Валентина Галич здійснила дослідження проблемного поля есеїстики В. Бендера [5]. В полі зору досліджень автора цієї статті - ідейно-естетичні домінанти роману «Фронтові дороги» [2], поетикальний вимір малої прози Віталія Бендера [3].

Iз нечисленності згаданих спроб фахового осягнення доробку письменника-емігранта випливає необхідність систематичного аналізу художніх та публіцистичних текстів Віталія Бендера, визначення їх своєрідності як на зовнішньому, так і на внутрішньому рівнях будови літературного твору. Актуальним постає питання спеціального дослідження формально-змістових особливостей епіки письменника, зокрема питань, що стосуються фабульної організації його творів.

Мета статті - визначення фабульної стратегії роману Віталія Бендера «Марш молодости». Завдання статті - шляхом визначення специфіки фабульної організації роману «Марш молодости» виокремити типологічні ознаки наративної своєрідності зазначеного твору. Об'єктом дослідження обрано роман «Марш молодости».

Якщо у британському вимірі свого буття Бендер залишив по собі спогади як фаховий журналіст, ведучий славнозвісного радіо ВВС та автор злободенної й літературно-критичної публіцистики, діяч українського еміграційного руху, то до української літератури він увійшов насамперед як письменник, що створив низку вартісних епічних творів, що підтверджують його питому приналежність до вітчизняної культурної традиції. У малих та 
великих епічних формах Віталієм Бендером витворювалися моделі та візії національного буття українського народу очима типового його представника - вихідця зі степової Донеччини, доля якого відображає життєві колізії «біографічного» автора.

Своєрідну епічну трилогію Бендера складають романи «Станція Пугаловська», «Фронтові дороги» та «Марш молодости». Ці твори подані не за послідовністю публікації, а за хронологією охоплюваних ними періодів. Так, «Станція Пугаловська» зображує довоєнне життя маленького містечка в донецьких степах, дія твору охоплює також перші місяці після оголошення війни. Роман «Фронтові дороги» змальовує шлях протагоніста «Станції Пугаловської» - Михайла Мартюка в лавах Червоної Армії.

Зображувані в «Марші молодости» події хоч формально й не поєднані 3 попередніми двома творами спільним головним героєм, проте біографічно $є$ дотичними до реальних життєвих випробувань Віталія Бендера в лавах Першої дивізії УНА. Цей твір є першим за хронологією написання 3-поміж інших складових автобіографічної трилогії. Автор розпочав роботу над ним ще під час перебування в таборі для інтернованих вояків УНА в італійському містечку Ріміні, а завершив уже на англійській землі 1953 року. Незначний проміжок часу, що минув між описуваними подіями та роком завершення роботи над романом, свідчить про необхідність у максимально об' єктивному трансформуванні життєвої дійсності в художній текст, що стояла перед письменником, який крізь романну подієвість передає власний військовий досвід.

Зовнішня форма твору є експліцитним чинником його структурнокомпозиційної організації. Фабула постає ключовим рушієм організації художнього тексту, становить послідовний виклад зображуваних у ньому подій.

У «Літературній енциклопедії» фабула художнього твору визначена як фактичний бік оповіді, тобто події, випадки, дії, стани в їх причиновохронологічній послідовності, i, таким чином, їі відрізняють від сюжету, в 
якому вказані елементи компонуються й оформлюються автором на основі закономірностей, які вбачаються ним у розвитку зображуваних явищ [9].

Ще чіткіше розмежування фабули й сюжету було здійснене Б. В. Томашевським: «Фабулою називається сукупність подій, пов’язаних між собою, про які повідомляється у творі. Фабулі протистоїть сюжет: ті самі події, але в їх викладі, в тій послідовності, в якій вони повідомлені у творі, в тому зв’язку, в якому подані у творі повідомлення про них» [13, с. 119].

В.І.Тюпа пропонує загальну чотирифазову модель фабульної організації художнього тексту: «3 позицій історичної поетики набагато ефективнішим є використання при аналізі сюжету з оригінальною фабулою (не кажучи вже про фабули традиційні) системи історично сформованих фаз сюжетного розгортання тексту. До числа цих фаз уходять послідовно: фаза виокремлення, фаза партнерства, лімінальна фаза випробування смертю i фаза перетворення» [14, с. 39]. Зазначена модель є робочою для нашого дослідження.

Відповідно до запропонованої В. І. Тюпою схеми фабульної організації художнього тексту для роману «Марш молодости» початковою $є$ фаза виокремлення. Першим ऑï етапом постає окреслення хронотопічних характеристик твору, виділення провідних його дійових осіб. На цій стадії показано шляхи формування «спеціяльної сотні», подано історію їі існування до початку керівництва сотником Сіроштаном зазначеним бойовим загоном, що поданий крізь призму сприйняття хорунжого Чиговського, позначену конотацією певного дискомфорту від майбутньої служби під проводом визначного командувача: «Його [тобто Чиговського. - А. Б.] призначення в сотню Сіроштана сталося так несподівано і нагло, що навіть ніколи зробити прохання до командира полку про зміну рішення» [1, с. 473]. Ефект несподіванки посилює враження вимушеного оповідача від першої зустрічі 3 представниками підрозділу, де доведеться служити. Ця перша зустріч відбувається за доволі несприятливих обставин для обох іiі сторін Чиговський невдало жартує 3 вояками i падає 3 коня, проте ймовірний 
конфлікт пом'якшується людяною поведінкою хорунжого в подальших контактах із підлеглими: «Незнайомий дістав з бокової кишені якісь папери і, подаючи їх хлопцям, смирніше промовив: «Хорунжий Чиговський! Зі штабу полку»» [1, с. 469]. Проте вже тоді окреслюється вторинність ролі Чиговського щодо сотника Сіроштана, який став своєрідним «батьком» для спеціяльної сотні.

Фігура сотника Сіроштана $є$ центральною у цій фазі розгортання сюжету твору. Навколо неї твориться вся новітня історія спеціальної сотні, яку саме Сіроштан урятував від знищення, що неминуче чекало б на іiі вояків після придушення бунту в Словаччині. Ім'я Сіроштана міфологізується, обростає численними подробицями, що їм ніхто не йме віри через таємничість Сіроштанової акції з перевиховання сотні: «Казали тоді, що Сіроштан добровільно погодився перебрати сотню і втихомирити хлопців без ужиття карної зброї. За два дні згадана сотня знову виглядала бойовою одиницею, а Сіроштан так і залишився іiі командиром. Кружляли чутки, немов би при утихомиренні він проявив незвичайну жорстокість, проте ці вістки ніколи не були підтверджені, i сам Чиговський також не йняв їм віри» [1, с. 473]. Формула «казали тоді» наближає спогади про виховну роботу Сіроштана в спеціальній сотні до фольклорної основи, зокрема до казкового чи переказового тексту, в якому певні надзвичайні події не лишили по собі живих свідків, а відомості про них подаються лише з чужих вуст.

Певну винятковість, міфологічність постаті командира надають і такі риси його характеру, як відчайдушна сміливість та виняткова чесність перед підлеглими, що виявляється в конкретних учинках. Так, під час уже згаданого придушення повстання в спеціальній сотні Сіроштан без тіні сумніву йде назустріч стрільцеві, що наставив на нього автомат. Проте відсутність страху перед смертю, готовність іти до кінця та відмова від одвічних упереджень у конфлікті командира та підлеглого змушує сотню довіритися Сіроштану і визнати його владу над собою: «Відтоді Сіроштан 
став невеликим диктатором, слово якого беззастережно виконувалось 150 молодими стрільцями» [1, с. 484].

Друга фаза - фаза партнерства - виявляється в романі на різних етапах розвитку його сюжету. Вона реалізується шляхом встановлення нових міжсуб'єктних зв'язків, зокрема набуття героєм «помічників» або «шкідників» [14, с. 39]. Так, початковою стадією фази партнерства виявляються стосунки Ігоря Сіроштана та медсестри Наді, які зародилися ще до початку романної дії, а на час прибуття хорунжого Чиговського до сотні набули кризового характеру: «... Перебрала в думках свої взаємини 3 Сіроштаном. Непомітно прийшла до висновку, що іiі пристрасті до нього були тимчасовими. Вона [Надя. - А. Б. ] усвідомила, що Сіроштан з'явився на іiі шляху як спокуса, від якої неможливо було втекти» [1, 496]. Відповідно надалі розгортається виникнення нових партнерств. Так, Сіроштан знаходить утіху в обіймах австрійської білявки Берти, яка не вимагає до себе особливої уваги й готова сумлінно нести звання похідно-полкової дружини, а Надя стрімко закохується в новоприбулого хорунжого Чиговського: «Та думкою вона вже втікала геть, бо наостанку пригадався Чиговський, молодий i поставний, з вольовим поглядом і чорними бровами» [1, с. 496].

Та ключовим елементом фази партнерства в розгортанні романного сюжету постають стосунки між двома командирами - сотником Сіроштаном та хорунжим Чиговським. Як пам'ятаємо, прибуття хорунжого до спеціальної сотні супроводжувалося відчутним скепсисом щодо постаті сотника, спровокованим, 3 одного боку, антагонізмом між галичанами та наддніпрянцями, що до певної міри був наявний у війську, а з іншого боку побоюванням з приводу надмірності диктатури Сіроштана в підрозділі, що могла б завадити Чиговському повноправно виконувати свої обов'язки в сотні. Додатковим чинником можливого розходження між сотником та хорунжим вірогідно могла стати медсестра Надя, яка закохалася в Чиговського. Проте схильність сотника до самопожертви заради інтересів загону сприяла уникненню конфлікту: «А Сіроштан взагалі не хотів якогось 
мосту через цю прірву. Він знав, що його характер ніяк не міг зробити цю квітучу дівчину щасливою... Тому він оминув Надю, відкинув іiі руку, розчарував іiі кохання до себе. Так краще. Для неї і для нього» [1, с. 517]. Відповідно, стосунки між Чиговським та Сіроштаном не лише не погіршуються, але й набувають ознак партнерства, необхідного для виконання поставлених перед ними бойових завдань, стають основою справжньої дружби.

Ще одним виміром фази партнерства у творі постає зустріч спеціальної сотні з українським полоненим, вояком-партизаном Дмитром Гнатенком. Ця людина, як і Чиговський, неоднозначно поставилася до сотні та їі командира: «... Бо ненавидів німецький стрій, і для нього, Гнатенка, кожний, хто одяг цей стрій на себе, автоматично ставав шкурником, вбивцею, людиною без серця» $[1$, с. 576]. Проте особисте спілкування з вояками та командуванням сотні змусило Дмитра змінити своє враження про неї, побачити в сотні ще один вимір українства, розкиданого по різні боки барикад на шляхах світової війни: «Ваші хлопці мають великі душі, і їхнє поводження з нами майже товариське... Я ніколи не думав знайти східняка командиром військової одиниці, що складається переважно з галичан» [1, с. 576]. Вирішальним моментом остаточного закріплення партнерства між колишнім партизаном та представниками спеціальної сотні $є$ епізод, під час якого Гнатенку дається можливість вибору свого майбутнього, проте Дмитро відмовляється від цієї пропозиції й вирішує пристати до сотні. Його аргументація є виявом найбільшої довіри до командування та надії на подальше братерство: «Він сказав «не вб’єте ж» так просто і так байдуже, немов би балачка йшла про шмат хліба, а не про ціну життя» [1, с. 577]. Таке ставлення до життя і смерті загалом характерне для парадигми цінностей воєнного часу, коли важливість щирих стосунків із найближчим товаришем $є$ набагато вищою за ризик втратити життя.

Перехід до лімінальної стадії розгортання романного сюжету на початкових своїх стадіях виявляє ознаки індивідуалізації, які, втім, із 
подальшим перебігом подій трансформуються й набувають усезагальності. Так, перші відчутні втрати спеціальна сотня несе навіть не через сутички 3 ворогом, а з причин особистісного характеру. Так, Зінченко і Коханюк знаходять свою смерть, прагнучи втамувати голод під час нічної варти. Коханюк гине, зневірившись у можливості відбитися від засідки югославських військ, а Зінченко вибирається до найближчого словенського села. Там він встигає познайомитися 3 молодою вдовою Феліцею та прожити останній день свого життя, максимально насичений емоціями та почуттями. Завдяки передсмертній ініціації Зінченкові вдається практично повністю відтворити в мініатюрі життєвий цикл людини, вдовольнивши не лише потребу в їжі та воді, але й інстинкт продовження роду. Перед тим, як полягти під кулями югославів, український вояк відтворює в пам’яті все пережите ним за цей день та доходить висновків, що підтверджують одвічний зв’язок між смертю та життям: «Він дивився їй услід і хотів відгадати, пощо доля кинула її йому назустріч? Для останньої втіхи? Чи для якоїсь іншої мети? Може, дала йому останню можливість продовжити себе біологічним законом? Доля...» [1, с. 631].

Проте найяскравішим вираженням лімінальної фази розвитку романного сюжету постає останній бій спеціальної сотні, що був прийнятий нею під час спроби прориву на територію Італії. Своєрідним мотто до цього етапу фабульної організації є промова Сіроштана, виголошена ним перед початком бою. Командир, звертаючись до своїх побратимів, намагається бути чесним перед ними, як і в той день, коли він уперше обійняв командування сотнею: «Буду відкритим: дехто з нас на останній ступінь ніколи не стане, бо за годину ми маємо прийняти вирішальний бій» [1, с. 670]. Сотник усвідомлює, що одним із тих, хто не перейде кордон, може стати він сам, тому заздалегідь готує своїх бійців до такого розвитку подій. Фактично це передсмертна промова, адже сотникові не потрібно бути провидцем, аби зрозуміти, що очікує на сотню під шквальним вогнем противників, бо союзників у неї немає. Зрештою, так і відбувається - бійці сотні жертвують 
своїм життям, аби подарувати товаришам можливість мирного повоєнного життя: «3 сто п’ятдесяти стрільців вісімдесят два дійшли до Італії живі й здорові... Сорок сім загубилися дорогою через червону землю» [1, с. 678].

Власне, вже з передсмертної промови фатально пораненого Сіроштана бере свій початок остання стадія фабульного розвитку романної подієвості фаза перетворення. Він свідомий того, що вмирає: «Я - труп, якому Творець не схотів на останку відібрати мови» [1, с. 676]. Спостерігаємо трансформацію всемогутнього, непідвладного кулям сотника, який ніколи не боявся смерті, в людину, яка помирає і при цьому щиро висловлює своє небажання залишати цей світ, вимагаючи від тих, хто його оточує, до кінця підтримувати розмову із ним, що є своєрідним символом життя: «... Хочу в останні свої хвилини багато говорити. Про все, про що лиш встигну... Хочу жити, разом з вами ділити радощі й болі життя...» [1, с. 676]. Останні хвилини Сіроштан зустрічає під акомпанемент гармонії Аркадія, яка супроводжувала його упродовж життєвого шляху й дістала роль своєрідного провідника у новий, потойбічний світ. Сотник не хоче, щоб його останні хвилини супроводжувалися сумом, тому просить свого вірного вояка заспівати улюблену пісню, аби розрадити загальну мінорну атмосферу у війську: «Не хочу плачу... Хочу пісні» [1, с. 676]. Сіроштан у цей момент вже не належить до світу живих, він переживає своєрідну ініціацію в новому світі, однак остаточно життя ще не полишив: «І я вже не тут... Одною ногою я там, де багато хлопців 3 нашої землі, про яких народ складає легенди й називає найкращими своїми синами...» [1, с. 676].

Варта уваги також і трансформація колишніх вояків після набуття ними статусу мирних громадян. Так, у випадку Чиговського це виявляється у зовнішніх перетвореннях: «Трошки постарів і на свої кучері тепер не звертає уваги» [1, с. 679]. Проте сила спогадів не дає трансформативним процесам досягнути повної викінченості, адже кожна зустріч старих побратимів по зброї викликає в пам’яті спогади про віддану війні молодість. Прохання Наді «трохи посумувати» $є$ знаком внутрішнього повернення в назавжди втрачені 
юні роки, сповнені звитягами і втратами: «... В ті моменти вони живуть молодістю й почувають себе молодо» [1, с. 680]. Тому, ймовірно, стверджувати про завершеність фази перетворення щодо зазначеної сюжетної лінії не зовсім доречно.

Таким чином, розвиток сюжетної організації роману Віталія Бендера «Марш молодости» відповідно до основних етапів фабульної схеми підтверджує тезу про існування певної «загальної чотирифазової моделі фабульної організації тексту» [14, с. 38]. Відтак актуальним є подальше дослідження творів письменника на основі класичних фабульних схем, що дозволяють, з одного боку, повніше розкрити їх загальнолюдський пафос i гуманістичну спрямованість, а 3 іншого - виявити ідейно-художню своєрідність аналізованих текстів.

\section{ЛІТЕРАТУРА} $888 \mathrm{c}$.

1. Бендер В. Марш молодости [Текст] / Віталій Бендер. - К.: Юніверс, 2005. -

2. Бузов А. С. Дискурс експресіонізму в романі Віталія Бендера «Фронтові дороги» [Текст] / Антон Сергійович Бузов // Актуальні проблеми української літератури і фольклору: наук. зб. - Випуск 23 / редкол.: В. А. Просалова (відп. ред.) та ін. - Вінниця: ДонНУ, 2015. - С. 70-79.

3. Бузов А. С. Стильові пошуки у малій прозі Віталія Бендера [Текст] / Антон Сергійович Бузов // Jahrbuch der VI Internationalen virtuellen Konferenz der Ukrainistik «Dialog der Sprachen - Dialog der Kulturen. Die Ukraine aus globaler Sicht» Reihe: Internationale virtuelle Konferenz der Ukrainistik. Діалог мов - діалог культур. Україна і світ. - Мюнхен: KUBON \& SAGNER, 2016. - C. 255-260.

4. Василенко Р. М. Ех, дороги [Текст] / Ростислав Миколайович Василенко // Життя в гримі та без (шляхами діаспори): мемуари, поезія, публіцистика. - К.: Рада, 1999. - C. 366-369.

5. Галич В. М. Публіцистика Віталія Бендера: жанрово-стильові домінанти [Текст] / Валентина Миколаївна Галич // Соціальні комунікації: теорія, історія, регіональний дискурс: науковий збірник / Редкол.: В. М. Галич (гол. ред.), К. М. Ульянова (заст. гол. ред), О. С. Куцевська, Ю. С. Соловйова, Н. С. Манич. Передм. К. М. Ульянової. - Рівне: О. Зень, 2015. - С. 23-46.

6. Дальний М. Вибране: Люди-події-коментарі [Текст] / Мар'ян Дальний; упоряд. О. Коновал. - К.: Видавничий дім «Києво-Могилянська академія», 2007. - 563 с.

7. Качуровський I. В. Покоління Другої світової війни в літературі української діаспори [Текст] / Ігор Васильович Качуровський // Променисті сильвети. - К.: КиєвоМогилянська академія, 2008. - С. 514-531.

8. Коновал О. Г. Жив з Україною в серці [Текст] / Олексій Григорович Коновал // Марш молодости. - К.: Юніверс, 2005. - С. 5-9.

9. Литературная энциклопедия [Електронний ресурс]. - Режим доступу: http://dic.academic.ru/dic.nsf/enc literature/4685/Фабула (Дата звернення: 01.04.2017). 
10. Мацько В. П. Українська еміграційна проза XX століття : монографія [Текст] / Віталій Петрович Мацько. - Хмельницький: ПП І.Ж.Дерепа, 2009. - 388 с.

11. Просалова B. A. Віталій Бендер [Текст] / Віра Андріївна Просалова // Українська діаспора: літературні постаті, твори, біобібліографічні відомості. - Донецьк: Східний видавничий дім, 2012. - С. 27.

12. Просалова B. A. Проблема автор - герой у романі Віталія Бендера «Фронтові дороги» [Текст] / Віра Андріївна Просалова // Вісник Донецького університету. Серія Б. Гуманітарні науки. - 2015. - № 1-2. - С. 208-213.

13. Томашевский Б. В. Теория литературы. Поэтика [Текст] / Б. В. Томашевский. М.: Аспект Пресс, 1999. - 334 с.

14. Tюna В. И. Анализ художественного текста [Текст] / В. И. Тюпа. - М.: Издательский центр «Академия», 2009. - 336 с.

\section{REFERENCES}

1. Bender V. Marsh molodosty [The March of Youth], Kyiv, Yunivers, 2005, 888 p [In Ukrainian].

2. Buzov A. Dyskurs ekspresionizmu v romani Vitaliya Bendera «Frontovi dorogy» [Expressionistic discourse of the novel "Front-line roads" by Vitaly Bender], Aktual ni problemy ukrayins koyi literatury $i$ fol kloru: nauk. $z b$. [Actual problems of literature and folklore: collection of scientific works], No. 23, Vinny`cya, DonNU, 2015, pp. 70-79 [In Ukrainian].

3. Buzov A. S. Styl'ovi poshuky u maliy prozi Vitaliya Bendera [Searching of style in the small prose by Vitaly Bender], Jahrbuch der VI Internationalen virtuellen Konferenz der Ukrainistik "Dialog der Sprachen - Dialog der Kulturen. Die Ukraine aus globaler Sicht» Reihe: Internationale virtuelle Konferenz der Ukrainistik. Dialog mov - dialog kul 'tur. Ukrayina $i$ svit [Dialogue of languages - dialogue of cultures. Ukraine and world], Munchen, KUBON \& SAGNER, 2016, pp. 255-260 [In Ukrainian].

4. Vasy lenko R. M. Ekh, dorogy [Oh, this roads], Zhyttya v grymi ta bez (shlyakhamy diaspory): memuary, poeziya, publitsystyka [The life in make-up and without (on the emigrate roads): memoires, poetry, publicism], Kyiv, Rada, 1999, pp. 366-369 [In Ukrainian].

5. Galy`ch V. M. Publitsystyka Vitaliya Bendera: zhanrovo-styl'ovi dominanty [Publicism of Vitaly Bender: genre-style dominants], Social ni komunikaciyi: teoriya, istoriya, regional`ny`j dy`skurs: naukovy`j zbirny`k [Social communications: theory, history, regional discourse: collection of scientific works], Rivne, O. Zen`, 2015, pp. 23-46 [In Ukrainian].

6. Dalinyj $M$. Vybrane: Lyudy-podiyi-komentari [Selected works: peopledevelopments-comments], Kyiv, Vydavnychyy dim «Kyyevo-Mohylyans'ka akademiya», 2007, 563 p [In Ukrainian].

7. Kachurovs `ky`j I. V. Pokolinnya Drugoyi svitovoyi viyny v literaturi ukrayins'koyi diaspory [Generation of WWII in the literature of ukrainian emigration], Promenysti syl'vety [Radiant silhouettes], Kyiv, Ky`yevo-Mogy`lyans`ka akademiya, 2008, pp. 514-531 [In Ukrainian].

8. Konoval O. G. Zhyv z Ukrayinoyu v sertsi [He lived with Ukraine in his heart], Marsh molodosty [The March of Youth], Kyiv, Yunivers, 2005, pp. 5-9 [In Ukrainian].

9. Literaturnaya entsyklopediya [Literary encyclopedia], Available on: http://dic.academic.ru/dic.nsf/enc_literature/4685/Fabula.

10. Mats ${ }^{`}$ o $V$. P. Ukrayins'ka emigraciyna proza XX stolittya : monografiya [The prose of ukrainian emigration: the monograph], Khmelnytskyy, PP I.Zh.Derepa, 2009, 388 p [In Ukrainian].

11. Prosalova V. A. Vitaliy Bender [Vitaly Bender], Ukrayins`ka diaspora: literaturni postati, tvory, biobibliografichni vidomosti.[Ukrainian diaspore: literary figures, works, biobibliographical information], Donets'k: Skhidnyy vydavnychyy dim, 2012, p. 27 [In Ukrainian]. 
12. Prosalova V. A. Problema avtor - geroy u romani Vitaliya Bendera «Frontovi dorogy» [The problem ,author - hero" in the novel "Front-line roads" by Vitaly Bender] Visnyk Donet'skogo universytetu. Seriya B. Gumanitarni nauky [The messenger of Donetsk National University. Series B. Human Sciences], 2015, No. 1-2, pp. 208-213 [In Ukrainian].

13. Tomashevskiy B. V. Teoriya literatury. Poetika [Theory of the literature. Poetics], Moskva, Aspekt Press, 1999, 334 p [In Russian].

14. Tyupa V. I. Analiz khudozhestvennogo teksta [The analysis of literary text], Moskva, Izdatel'skiy centr «Akademiya», 2009, 336 p [In Russian].

\begin{abstract}
АННОТАЦИЯ
Антон Бузов. Фабульная организация романа Виталия Бендера «Марш молодости»

В статье осуществлен фабульный анализ текста романа украинского писателя-эмигранта Виталия Бендера «Марш молодости» в соответствии с системой сюжетного развития художественного текста. В произведении последовательно выделены фазы обособления, установления партнерства, смертельного испытания, перевоплощения. Использование классических сюжетных схем во время исследования литературного наследия украинской диаспоры позволяет полнее раскрыть не только общечеловеческий пафос и гуманистическую направленность этих текстов, но и их идейно-эстетическое своеобразие.

Ключевые слова: роман, эмиграция, фабула, сюжет, система сюжетного развития, поэтика
\end{abstract}

\begin{abstract}
Anton Buzov. Plot arrangement of the novel «The March of Youth» by Vitaly Bender

The article provides plot analysis of the text of the novel by the Ukrainian writer-emigrant Vitaly Bender "The March of Youth" in accordance with the system of plot development of a literary text. The plot is understood by the author as the actual side of the narrative, as events, actions, states in their causal-chronological order. Thus, the plot differs from the story in which these elements are assembled and formed by the author on the basis of the regularities that he observes in the development of the phenomena depicted.

It is a question of the traditional model of the fable organization of a literary work. The initial phase in this system is the phase of isolation. At this stage, the spatial and temporal characteristics of the work, its key actors, are singled out. The second phase - the phase of partnership - Is manifested in the novel at different stages in the development of its plot. It is realized through the establishment of new intersubject connections, in particular, the acquisition by the hero of "helpers" or "wreckers". The transition to the liminal stage symbolizes the beginning of a direct confrontation with death. The phase of transformation is a complex of spiritual changes of the main characters after the death test.

Vitaly Bender consistently identifies the stages of isolation, establishing partnership, ordeal, transfiguration. At each of these stages, new challenges arise in front of the heroes of the novel, connected with the search for their own place in life. Using the classical scenarios during the study of the literary heritage of the Ukrainian diaspora allows fully disclosing not only their human pathos and humanistic orientation but also ideological and artistic and national originality.
\end{abstract}

Key words: novel, diaspora, plot, story, system of plot development, poetics. 